Article

\title{
Tin-Naphthalene Sulfonic Acid Complexes as Photostabilizers for Poly(vinyl chloride)
}

\author{
Hadeer Jasem ${ }^{1}$, Angham G. Hadi ${ }^{1}\left(\mathbb{D}\right.$, Gamal A. El-Hiti ${ }^{2, *}{ }^{7}$, Mohammed A. Baashen ${ }^{3}{ }^{(D}$, Hassan Hashim ${ }^{4}$, \\ Ahmed A. Ahmed ${ }^{5}$, Dina S. Ahmed ${ }^{6}$ and Emad Yousif ${ }^{7}$
}

1 Department of Chemistry, College of Science, University of Babylon, Babylon 51002, Iraq; hadeer.abd_alhussain@student.uobabylon.edu.iq (H.J.); sci.angam.ganem@uobabylon.edu.iq (A.G.H.)

2 Cornea Research Chair, Department of Optometry, College of Applied Medical Sciences, King Saud University, P.O. Box 10219, Riyadh 11433, Saudi Arabia

3 Department of Chemistry, College of Science and Humanities, Shaqra University, Dawadmi 11911, Saudi Arabia; mbaashen@su.edu.sa

4 Department of Physics, College of Science, Al-Nahrain University, Baghdad 64021, Iraq; hassan.hashim@ced.nahrainuniv.edu.iq

5 Polymer Research Unit, College of Science, Al-Mustansiriyah University, Baghdad 10052, Iraq; dr_ahmedabd@uomustansiriyah.edu.iq

6 Department of Medical Instrumentation Engineering, Al-Mansour University College, Baghdad 10067, Iraq; dina.saadi@muc.edu.iq

7 Department of Chemistry, College of Science, Al-Nahrain University, Baghdad 64021, Iraq; emad.yousif@ced.nahrainuniv.edu.iq

* Correspondence: gelhiti@ksu.edu.sa; Tel.: +966-11469-3778; Fax: +966-11469-3536

Citation: Jasem, H.; Hadi, A.G.; El-Hiti, G.A.; Baashen, M.A.; Hashim, H.; Ahmed, A.A.; Ahmed, D.S.; Yousif, E. Tin-Naphthalene Sulfonic Acid Complexes as Photostabilizers for Poly(vinyl chloride). Molecules 2021, 26, 3629. https://doi.org/ $10.3390 /$ molecules 26123629

Academic Editor: Julia Romanova

Received: 26 May 2021

Accepted: 11 June 2021

Published: 14 June 2021

Publisher's Note: MDPI stays neutral with regard to jurisdictional claims in published maps and institutional affiliations.

Copyright: (c) 2021 by the authors. Licensee MDPI, Basel, Switzerland. This article is an open access article distributed under the terms and conditions of the Creative Commons Attribution (CC BY) license (https:// creativecommons.org/licenses/by/ $4.0 /)$.
Abstract: Poly(vinyl chloride) degrades when exposed to ultraviolet light for long durations; therefore, the photostability of polymeric materials should be enhanced through the application of additives. New organotin complexes containing 4-aminonaphthalene-1-sulfonic acid were synthesized and their role as poly(vinyl chloride) photostabilizers were evaluated. The reaction of 4-amino-3hydroxynaphthalene-1-sulfonic acid and appropriate di- or trisubstituted tin chloride (triphenyltin chloride, tributyltin chloride, dibutyltin dichloride, and dimethyltin dichloride) in methanol under reflux gave the corresponding tin-naphthalene complexes with yields of 75\%-95\%. Elemental analyses and spectroscopic techniques including infrared and nuclear magnetic resonance (proton and tin) were used to confirm their structures. The tin complexes were added to poly(vinyl chloride) to produce thin films that irradiated with ultraviolet light. Various parameters were assessed, such as the weight loss, formation of specific functional groups, changes in the surface due to photoirradiation, and rate constant of photodegradation, to test the role played by the organotin complexes to reduce photodegradation in polymeric films. The results proved that organotin complexes acted as photostabilizers in these circumstances. The weight loss, formation of fragments containing specific functional groups, and undesirable changes in the surface of polymeric films were limited in the presence of organotin complexes. Organotin complexes containing three phenyl groups showed the most desirable stabilization effect. These act as efficient primary and secondary photostabilizers, and as decomposers for peroxides. In addition, such an additive inhibits the dehydrochlorination process, which is the main cause of poly(vinyl chloride) photodegradation.

Keywords: poly(vinyl chloride); tin-naphthalene sulfonic acid complexes; photostabilizers; weight loss; ultraviolet irradiation; thin films; surface morphology; photodegradation

\section{Introduction}

Plastics are large molecular mass polymers that have very useful properties that enable their adaptation to various applications. They are strong, durable, stable, can be molded at a high temperature, and can resist fire, weather, and chemicals [1,2]. Plastics can be used in sports and medical equipment, construction, automotive manufacturing, 
electronics, toys, packaging, bottles, containers, and plastic bags. Poly(vinyl chloride) $(\mathrm{PVC})$ is a common thermoplastic polymer that is commonly produced on a commercial scale [3]. In terms of production and consumption, PVC is second to polyolefins due to its unique properties and low production cost [4]. PVC is produced in various forms mainly as a flexible (plasticized with a low degree of crystallinity) or rigid (non-plasticized with a high degree of crystallinity) material [5]. It has unique properties; however, it suffers from weathering due to long term exposure to ultraviolet (UV) light, humidity, and high temperatures (above $100{ }^{\circ} \mathrm{C}$ ) [6,7]. It is considered that UV light is the main cause of PVC photodegradation. The mechanism by which PVC photodegradation takes place is not well documented and various speculations have been made $[8,9]$. The photodegradation of PVC leads to the formation of small polyene fragments, a decrease in molecular mass, a reduction in durability and strength, cracks, discoloration, and loss of mechanical properties [10-12]. Various additives have been added to PVC to increase its photostability and life time. These PVC additives mainly act as UV absorbers, radical decomposers, and energy quenchers $[13,14]$. Therefore, suitable photostabilizers should be mixed with PVC to prevent its decomposition and photooxidation. Such additives can preserve the mechanical and physical properties of PVC for a long time. These additives should be safe to use, not alter the color, blend well with the polymer, and be non-toxic and non-volatile. Recent research has concentrated on the development and use of new inexpensive PVC photostabilizers that contain aromatic moieties at a low concentration $[15,16]$. The most common PVC additives include Schiff bases containing aromatic moieties such as thiophene [17], 1,2,4-triazole [18], thiadiazole [19,20], and 4H-1,2,4-triazole-3-thiol [21]. They also include pigments [14], titanium dioxide [22,23], zinc oxide [24], polyphosphates [25], and polybenzimidazoles [26].

Organotin compounds are chemically and physically stable, and have been used in various pharmaceutical and medicinal applications [27]. For example, they act as antivirals against cancer [28], inflammatory agents [29], antimicrobials [30], and antiantitubercular agents [31]. In addition, they can be used as preservatives for wood, biocides, and catalysts [32,33]. Organotin compound performance was found to be dependent on the substituents attached to the tin in terms of their types (aliphatic, aromatic, or heterocyclic) and number [34]. Recently, we investigated the role played by tin complexes of mefenamic acid [35], carvedilol [36], and sodium fusidate [37] as PVC photostabilizers. In the current research, we report the design, synthesis, and use of new tin complexes of 4-amino-3hydroxynaphthalene-1-sulfonic acid as additives for PVC to reduce its photooxidation and photodegradation. These complexes are expected to work as efficient PVC photostabilizers compared with those reported because they are highly aromatic (e.g., naphthalene ring) and contain heteroatoms such as nitrogen, oxygen, and sulfur.

\section{Results and Discussion}

\subsection{Synthesis of Tin-Naphthalene Sulfonic Acid Complexes 1-4}

Four substituted tin-naphthalene sulfonic acid complexes were synthesized in high yields using a simple procedure. Reaction of a 1:1 mixture of 4-amino-3-hydroxynaphthalene1-sulfonic acid (ligand) and triphenyl- and tributyltin chlorides in refluxing methanol $(\mathrm{MeOH})$ for $4 \mathrm{~h}$ resulted in the corresponding trisubstituted tin complexes $\mathbf{1}$ and $\mathbf{2}$ with $65 \%$ and $70 \%$ yields, respectively (Scheme 1). Similarly, the reaction of the ligand (two mole equivalents) and dibutyl- and dimethyltin dichlorides resulted in disubstituted tin complexes 3 and 4 with 95\% and 89\% yields, respectively (Scheme 2). The yields (\%), color, and melting points (MPs) of tin-naphthalene sulfonic acid 1-4 are reported in Table 1. The purity of materials was established by the determination of the content (\%) of carbon, hydrogen, sulfur, and nitrogen (Table 1). 
<smiles>Nc1c(O)cc(S(=O)(=O)O)c2ccccc12</smiles>

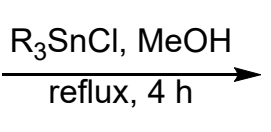<smiles>[R][Sb]([R])([R])Oc1cc(S(=O)(=O)O)c2ccccc2c1N</smiles>

$1, \mathrm{R}=\mathrm{Ph}$

2, $\mathrm{R}=\mathrm{Bu}$

Scheme 1. Synthesis of tri-substituted tin-naphthalene sulfonic acid complexes $\mathbf{1}$ and $\mathbf{2}$.

2<smiles>Nc1c(O)cc(S(=O)(=O)O)c2ccccc12</smiles>

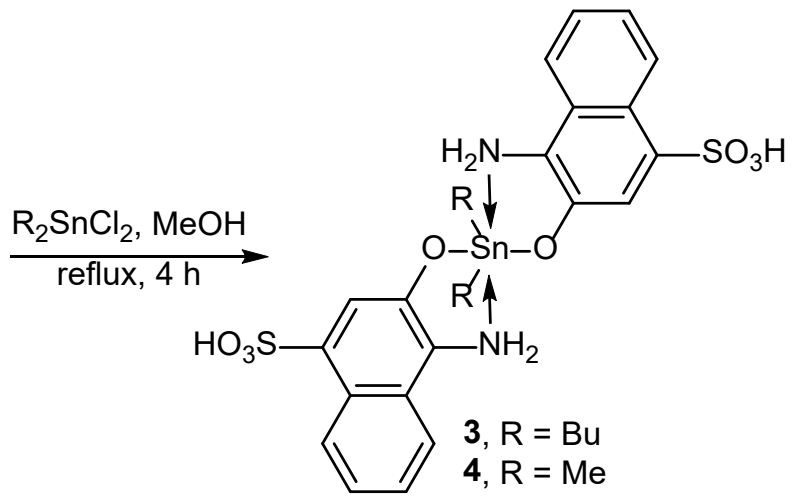

Scheme 2. Synthesis of di-substituted tin-naphthalene sulfonic acid complexes 3 and 4.

Table 1. Physical properties of tin-naphthalene sulfonic acid complexes 1-4.

\begin{tabular}{cccccccc}
\hline \multirow{2}{*}{ Complex } & \multirow{2}{*}{ Color } & \multirow{2}{*}{ Yield (\%) } & \multirow{2}{*}{ MP $\left({ }^{\circ} \mathbf{C}\right.$ ) } & \multicolumn{4}{c}{ Elemental Analysis (\%) Calculated (Found) } \\
\cline { 5 - 7 } & & & $\mathbf{C}$ & $\mathbf{H}$ & $\mathbf{N}$ & $\mathbf{S}$ \\
\hline $\mathbf{1}$ & Pale pink & 75 & $213-215$ & $57.17(56.95)$ & $3.94(4.02)$ & $2.38(2.26)$ & $5.45(5.61)$ \\
$\mathbf{2}$ & Pale purple & 70 & $150-152$ & $50.02(50.16)$ & $6.68(6.61)$ & $2.65(3.72)$ & $6.07(6.27)$ \\
$\mathbf{3}$ & Dark gray & 95 & $166-167$ & $47.40(47.62)$ & $4.83(4.87)$ & $3.95(4.77)$ & $9.04(9.11)$ \\
$\mathbf{4}$ & Pale purple & 89 & $243-245$ & $42.26(42.37)$ & $3.55(4.72)$ & $4.48(4.68)$ & $10.26(10.33)$ \\
\hline
\end{tabular}

\subsection{IR Spectroscopy of Tin-Naphthalene Sulfonic Acid Complexes 1-4}

The infrared (IR) spectra of 1-4 have distinguished bands that appeared within the regions of 3240-3314 $\mathrm{cm}^{-1}, 1597-1611 \mathrm{~cm}^{-1}$, and 1526-15301 $\mathrm{cm}^{-1}$, which are related to the vibrations of the $\mathrm{NH}_{2}, \mathrm{C}-\mathrm{N}$, and $\mathrm{C}-\mathrm{O}$ groups, respectively (Table 2). The high shift seen in the wave length of the vibrations of these groups compared with those for the ligand proved that the complexation between the ligand and tin had taken place [38]. In addition, the disappearance of the stretching vibration of the $\mathrm{O}-\mathrm{H}$ group in the tin complexes, which appeared at $3442 \mathrm{~cm}^{-1}$ for the ligand, provides further evidence of the complexation. New bands corresponding to the stretching vibrations of the $\mathrm{Sn}-\mathrm{C}\left(515-518 \mathrm{~cm}^{-1}\right)$ and $\mathrm{Sn}-\mathrm{O}$ $\left(455-518 \mathrm{~cm}^{-1}\right)$ were seen in the IR spectra of $1-4$. The assignments of these peaks were consistent with those reported for related compounds [39,40]. No shift was seen in the symmetric and asymmetric vibrations of the $\mathrm{SO}_{2}$ group in complexes 1-4 compared with those for the ligand. 
Table 2. IR spectral data of tin-naphthalene sulfonic acid complexes 1-4.

\begin{tabular}{cccccc}
\hline Complex & $\mathbf{N H}_{\mathbf{2}}$ & $\mathbf{C}-\mathbf{N}$ & $\mathbf{C}-\mathbf{O}$ & $\mathbf{S n - C}$ & Sn-O \\
\hline $\mathbf{1}$ & 3244 & 1608 & 1528 & 517 & 455 \\
$\mathbf{2}$ & 3314 & 1611 & 1526 & 518 & 457 \\
$\mathbf{3}$ & 3240 & 1597 & 1530 & 515 & 468 \\
$\mathbf{4}$ & 3246 & 1611 & 1528 & 515 & 472 \\
\hline
\end{tabular}

\subsection{NMR Spectroscopy of Tin-Naphthalene Sulfonic Acid Complexes 1-4}

The ${ }^{1} \mathrm{H}$ and ${ }^{119}$ Sn NMR spectral data of tin-naphthalene sulfonic acid complexes 1-4 confirmed their structures (Table 3). The ${ }^{1} \mathrm{H}$ NMR spectra showed the presence of two exchangeable broad singlets that appeared within the regions of 11.01-11.06 ppm and 9.78-9.84 ppm corresponding to the $\mathrm{SO}_{3} \mathrm{H}$ and $\mathrm{NH}_{2}$ protons, respectively. They also showed the presence of protons corresponding to naphthyl and substituent groups. The ${ }^{119} \mathrm{Sn}$ NMR spectra showed the presence of a singlet that appeared at the $-167.0 \mathrm{ppm}$ to the $-274.1 \mathrm{ppm}$ region. The chemical shifts for the tin atom indicated that the coordination number for the complexes $\mathbf{1}$ and $\mathbf{2}$ is five, whereas complexes $\mathbf{3}$ and $\mathbf{4}$ have a coordination number of six [41-43].

Table 3. ${ }^{1} \mathrm{H}$ and ${ }^{119}$ Sn NMR spectral data (DMSO- $d_{6}$; ppm, Hz) of tin-naphthalene sulfonic acid complexes 1-4.

\begin{tabular}{|c|c|c|}
\hline Complex & ${ }^{1} \mathrm{H}$ & ${ }^{119} \mathrm{Sn}$ \\
\hline 1 & $\begin{array}{c}11.04\left(1 \mathrm{H}, \text { exch., s, } \mathrm{SO}_{3} \mathrm{H}\right), 9.78\left(2 \mathrm{H}, \text { exch., br s, } \mathrm{NH}_{2}\right), 8.81(1 \mathrm{H}, \mathrm{d}, J=8.1 \mathrm{~Hz} \\
\mathrm{Ar}), 7.92(1 \mathrm{H}, \mathrm{d}, J=8.1 \mathrm{~Hz}, \mathrm{Ar}), 7.88(1 \mathrm{H}, \mathrm{s}, \mathrm{Ar}), 7.58-7.37(17 \mathrm{H}, \mathrm{m}, \mathrm{Ar})\end{array}$ & -174.0 \\
\hline 2 & $\begin{array}{c}11.06\left(1 \mathrm{H}, \mathrm{s}, \mathrm{SO}_{3} \mathrm{H}\right), 9.84\left(2 \mathrm{H}, \text { exch., br s, } \mathrm{NH}_{2}\right), 8.80(1 \mathrm{H}, \mathrm{d}, J=8.0 \mathrm{~Hz}, \mathrm{Ar}) \\
7.89-7.84(2 \mathrm{H}, \mathrm{m}, \mathrm{Ar}), 7.59(1 \mathrm{H}, \text { app. } \mathrm{t}, J=8.0 \mathrm{~Hz}, \mathrm{Ar}), 7.42(1 \mathrm{H}, \text { app. t } \\
J=8.0 \mathrm{~Hz}, \mathrm{Ar}), 1.62-1.59\left(6 \mathrm{H}, \mathrm{t}, J=7.6 \mathrm{~Hz}, 3 \mathrm{CH}_{2}\right) 1.34-1.29\left(6 \mathrm{H}, \mathrm{m}, 3 \mathrm{CH}_{2}\right) \\
1.14-1.1\left(6 \mathrm{H}, \mathrm{m}, 3 \mathrm{CH}_{2}\right), 0.88(9 \mathrm{H}, \mathrm{t}, J=7.6 \mathrm{~Hz}, 3 \mathrm{Me})\end{array}$ & -167.0 \\
\hline 3 & $\begin{array}{c}11.01\left(2 \mathrm{H}, \mathrm{s}, 2 \mathrm{SO}_{3} \mathrm{H}\right), 9.80\left(4 \mathrm{H}, \text { exch., br s, } 2 \mathrm{NH}_{2}\right), 8.77(2 \mathrm{H}, \mathrm{d}, J=8.2 \mathrm{~Hz}, \mathrm{Ar}), \\
7.83-7.65(4 \mathrm{H}, \mathrm{m}, \mathrm{Ar}), 7.42(2 \mathrm{H}, \text { app. } \mathrm{t}, J=8.2 \mathrm{~Hz}, \mathrm{Ar}), 7.28(2 \mathrm{H}, \text { app. t }, J=8.2 \\
\mathrm{Hz}, \mathrm{Ar}), 1.62-1.54\left(4 \mathrm{H}, \mathrm{t}, J=7.5 \mathrm{~Hz}, 2 \mathrm{CH}_{2}\right) 1.46-1.23\left(8 \mathrm{H}, \mathrm{m}, 4 \mathrm{CH}_{2}\right), 0.82(6 \mathrm{H}, \\
\mathrm{t}, J=7.5 \mathrm{~Hz}, 2 \mathrm{Me})\end{array}$ & -274.1 \\
\hline 4 & $\begin{array}{c}11.03\left(2 \mathrm{H}, \mathrm{s}, 2 \mathrm{SO}_{3} \mathrm{H}\right), 9.74\left(4 \mathrm{H}, \text { exch., br s, } 2 \mathrm{NH}_{2}\right), 8.81(2 \mathrm{H}, \mathrm{d}, J=8.0 \mathrm{~Hz}, \mathrm{Ar}) \\
7.90-7.85(4 \mathrm{H}, \mathrm{m}, \mathrm{Ar}), 7.58(2 \mathrm{H}, \text { app. } \mathrm{t}, J=8.0 \mathrm{~Hz}, \mathrm{Ar}), 7.41(2 \mathrm{H}, \text { app. t } \\
J=8.0 \mathrm{~Hz}, \mathrm{Ar}), 0.69(6 \mathrm{H}, \mathrm{s}, 2 \mathrm{Me})\end{array}$ & -242.5 \\
\hline
\end{tabular}

\subsection{Weight Loss of PVC}

Photooxidation, thermal decomposition, and photodegradation of PVC leads to hydrogen chloride (HCL) release and formation of polymeric chains containing double bonds (polyenes). The UV light absorption by PVC increases as more double bonds form (conjugated polyenes), leading to bond cleavage and formation of unsaturated fragments with a low molecular weight $[44,45]$. In addition, PVC develops discoloration, crosslinking, and scissions over time. The PVC mass loss becomes more noticeable as photodegradation proceeds. Therefore, the PVC photodegradation can be simply and efficiently assessed by measuring the mass loss. The PVC mass loss is the difference between the weight of non-irradiated $\left(W_{1}\right)$ and irritated $\left(W_{2}\right)$ film after a specific irradiation time. Complexes 1-4 were added to PVC at a concentration of $0.05 \%$ by weight and thin films $(40 \mu \mathrm{m})$ were produced. Such a concentration has been proven to be optimal to provide the most PVC protection without altering the color $[17,46]$. The blank and blended PVC films were irradiated (50 to $300 \mathrm{~h}$ ) at room temperature, and the weight loss (\%) of materials due to photodegradation was measured for different irradiation times using Equation (1). The results obtained are plotted and presented in Figure 1.

$$
\text { Weight loss }(\%)=\left[\left(W_{1}-W_{2}\right) / W_{1} \times 100\right.
$$




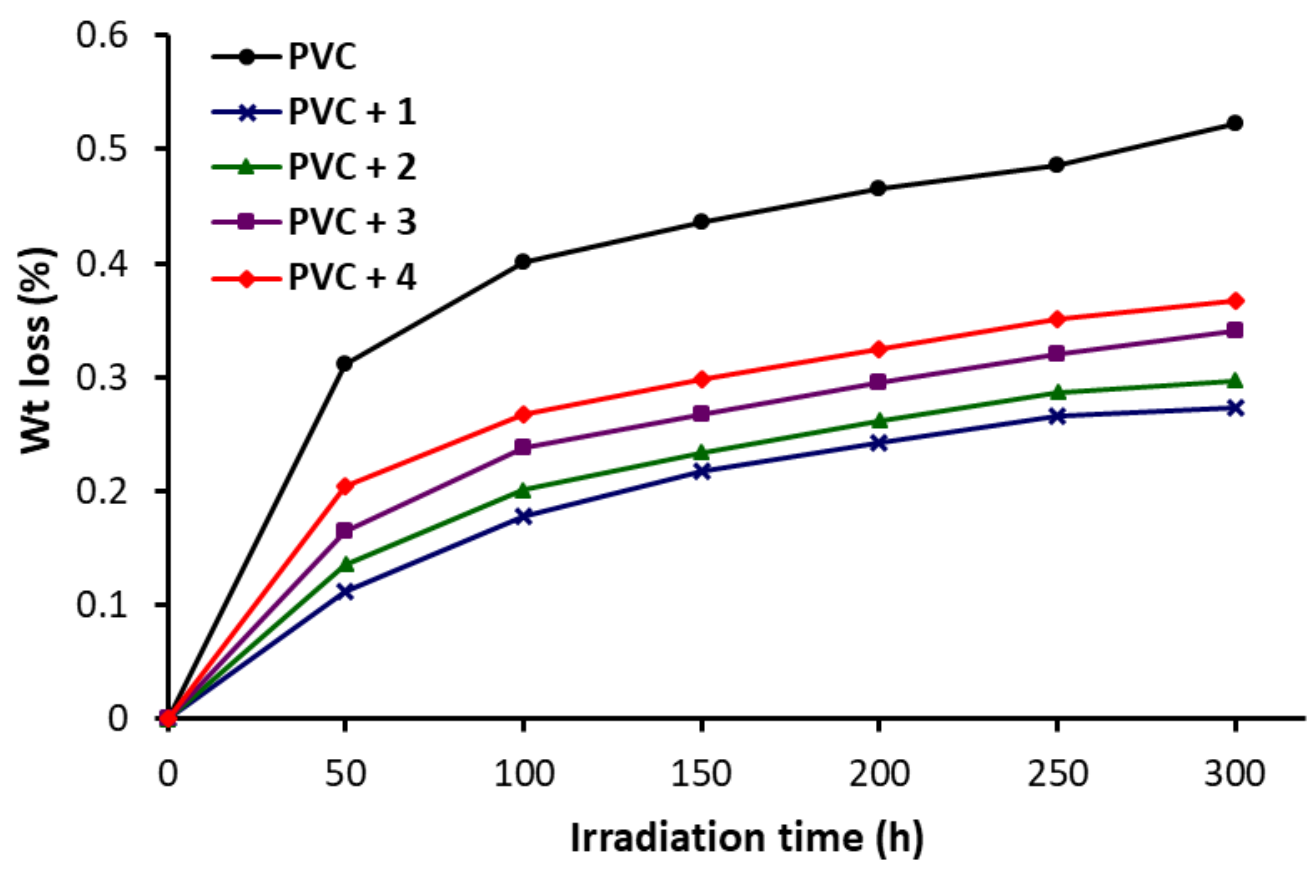

Figure 1. Effect of UV irradiation time on weight loss \% of PVC films.

Figure 1 shows that tin-naphthalene complexes 1-4 played a role in reducing the PVC weight loss due to UV irradiation. The weight loss (\%) after $50 \mathrm{~h}$ of irradiation was 0.312 for the blank film compared with 0.112 to 0.204 in the presence of tin-naphthalene complexes 1-4. After $300 \mathrm{~h}$ of irradiation, the weight loss (\%) for the blank PVC film was higher (0.523) than those obtained in the presence of the complexes used (0.273-0.341). The lowest weight loss $(\%)$ was seen for PVC +1 (0.273) followed by PVC $+2(0.297), P V C+3(0.341)$, and PVC +4 (0.367). It was clear that complex 1 was the most efficient PVC stabilizer due to its high degree of aromaticity (three phenyl groups). Aromatic rings and heteroatoms (sulfur, nitrogen, and oxygen) stabilized PVC through direct absorption of light or coordination with polymeric chains.

\subsection{IR Spectroscopy of PVC}

Irradiation of PVC with UV light leads to the formation of free radicals (e.g., $\mathrm{Cl}$, $-\mathrm{CH}_{2}-\mathrm{CH}$-radicals) [17,47]. These radicals are responsible for the formation of small polymeric fragments that contain double bonds (alkene, $-\mathrm{CH}=\mathrm{CH}-$ ). In the presence of oxygen, other fragments that contain carbonyl groups (e.g., ketone, $-\mathrm{CH}_{2}-\mathrm{CO}-$ ) and hydroxyl residues (e.g., alcohol, $-\mathrm{CH}_{2}-\mathrm{CHOH}-$ ) are produced. The use of IR spectroscopy can provide evidence about the growth in the intensity of peaks corresponding to the $\mathrm{OH}$ $\left(3500 \mathrm{~cm}^{-1}\right), \mathrm{C}=\mathrm{O}\left(1722 \mathrm{~cm}^{-1}\right)$, and $\mathrm{C}=\mathrm{C}\left(1602 \mathrm{~cm}^{-1}\right)$ functional groups [48-50]. Therefore, the blank and blended PVC films were irradiated for different durations that ranged from 50 to $300 \mathrm{~h}$. The IR spectra were recorded and the increase in the intensity of the peaks corresponding to hydroxyl, carbonyl, and alkene groups was measured. The IR spectra of pure PVC film before and after irradiation $(300 \mathrm{~h})$ are shown in Figure 2. The index for each functional group $\left(I_{S}\right)$ was calculated from the absorption of its peak $\left(A_{S}\right)$ and absorption of a reference peak $\left(A_{r}\right)$ using Equation (2) [51]. The reference peak corresponds to the $-\mathrm{CH}-$ bond $\left(1328 \mathrm{~cm}^{-1}\right)$ in PVC. The intensity of such a peak does not change during the irradiation process. The $I \mathrm{OH}, I \mathrm{C}=\mathrm{O}$, and $I \mathrm{C}=\mathrm{C}$ were calculated every $50 \mathrm{~h}$, and the results obtained are shown in Figures 3-5, respectively.

$$
I_{s}=A_{s} / A_{r}
$$



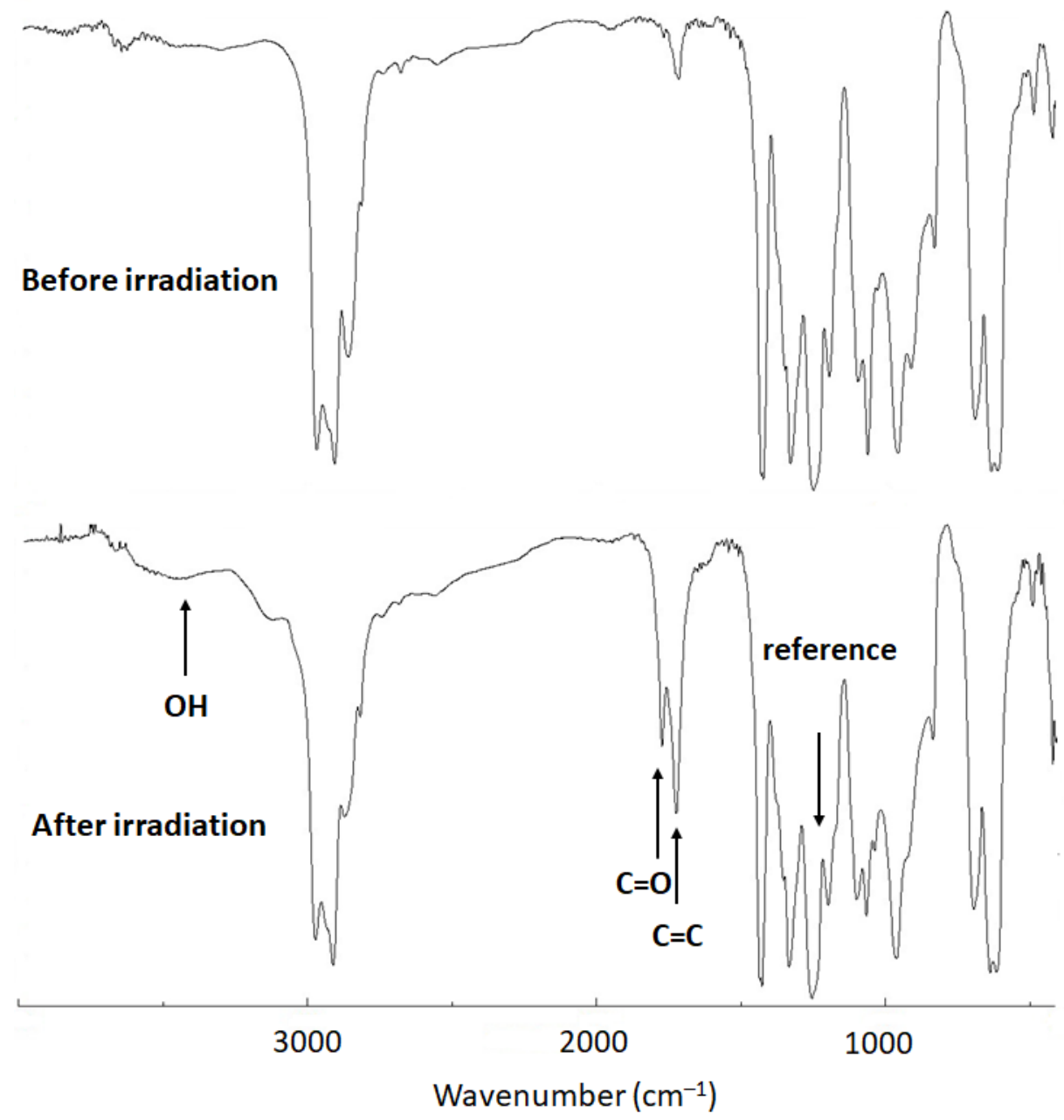

Figure 2. IR spectra of pure PVC film before and after irradiation.

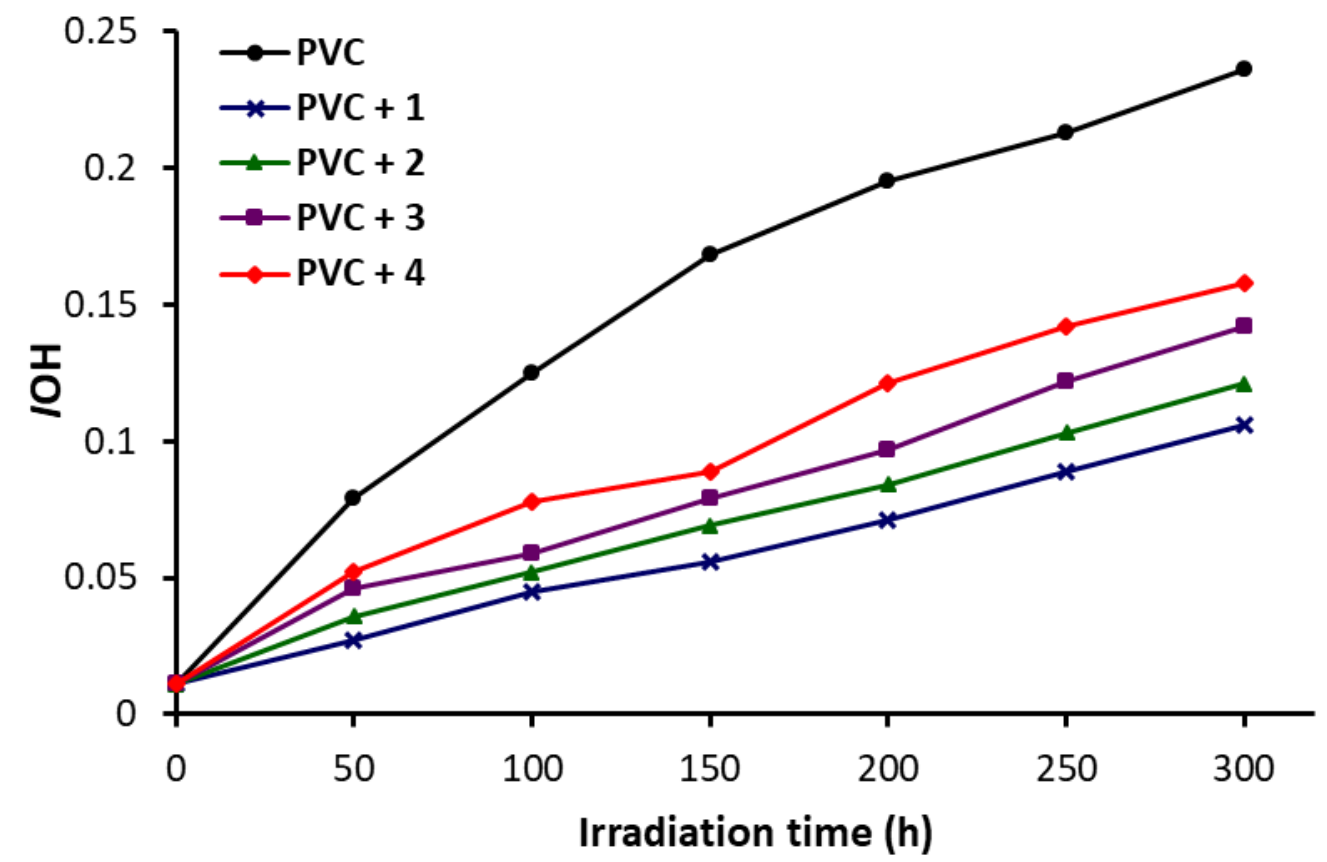

Figure 3. Effect of UV irradiation time on the $\mathrm{IOH}$ of PVC films. 


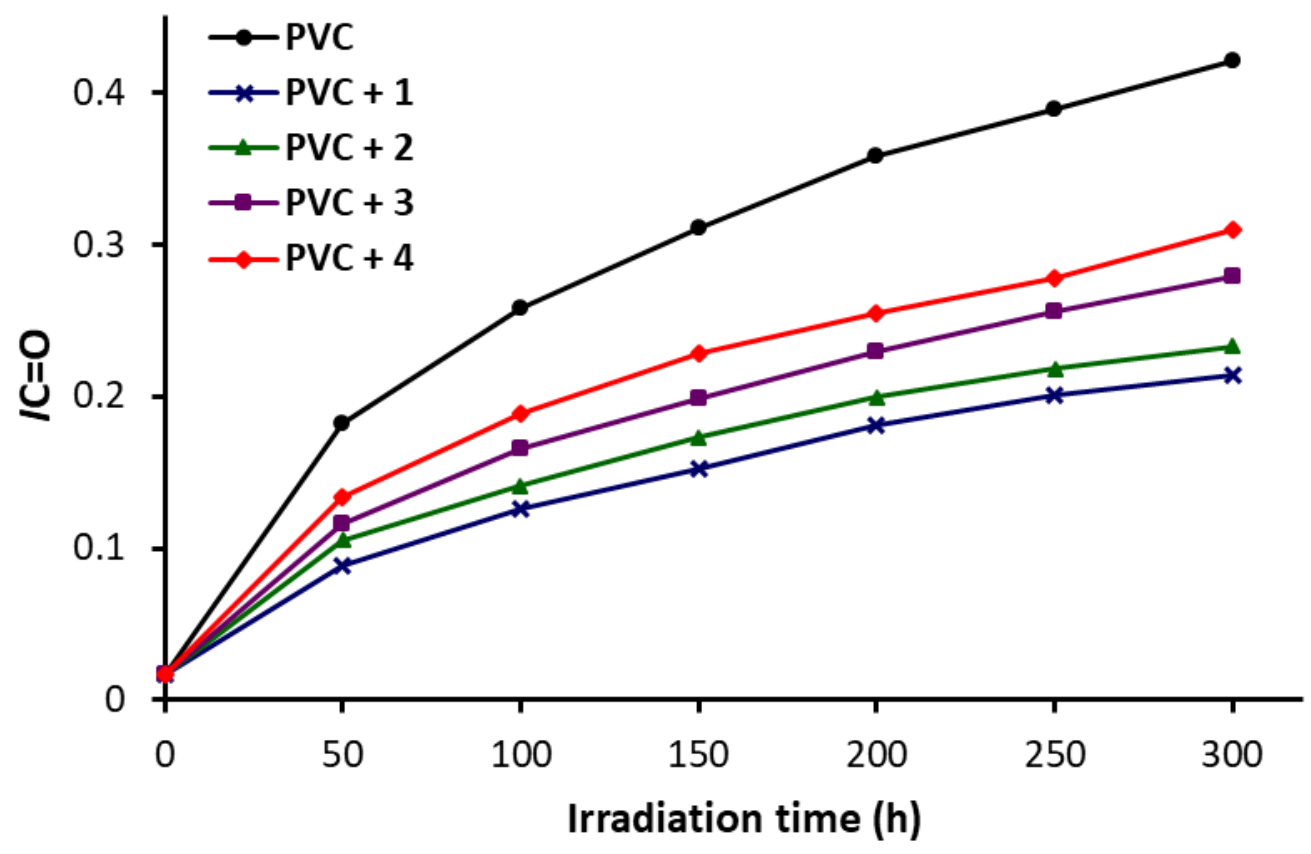

Figure 4. Effect of UV irradiation time on the $I C=\mathrm{O}$ of PVC films.

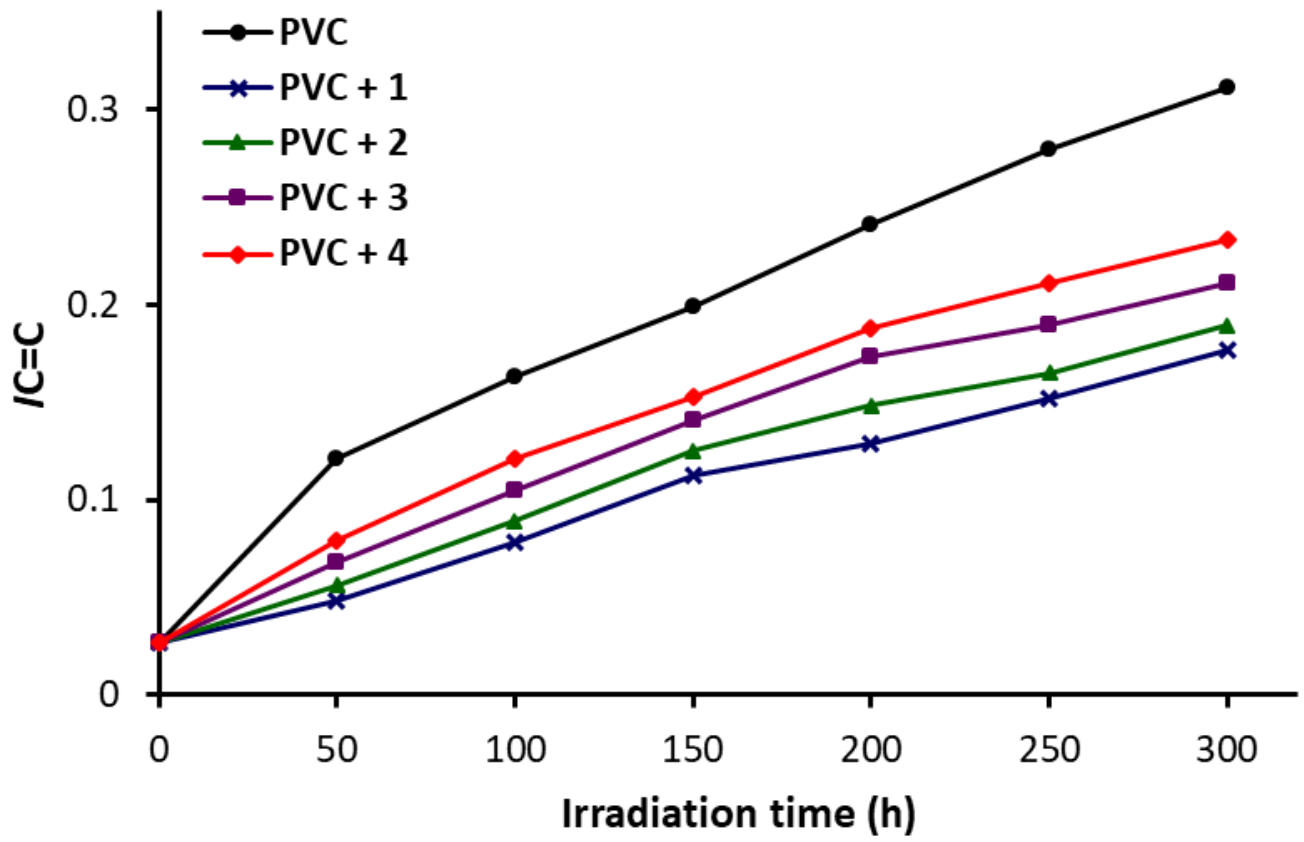

Figure 5. Effect of UV irradiation time on the $I C=C$ of PVC films.

Figures $3-5$ show a significant increase in the $\mathrm{IOH}, I \mathrm{C}=\mathrm{O}$, and $I \mathrm{C}=\mathrm{C}$ as irradiation time increased. The growth in functional group indices was very rapid in the first $50 \mathrm{~h}$. The changes were smaller when PVC was blended with tin-naphthalene complexes compared with those obtained for the blank film. Again, the highly aromatic additive (i.e., complex 1) was the most efficient PVC stabilizer. For example, the $I C=C$ for the blank PVC was 0.331 compared with 0.177 for the film containing 1 at the end of the irradiation process. Such a result indicated clearly that the used complexes acted as efficient stabilizers for PVC and significantly reduced the elimination of $\mathrm{HCl}$. Similarly, the $\mathrm{IOH}$ and $\mathrm{IC}=\mathrm{CO}$ for the blank PVC was 0.236 and 0.421 , respectively, compared with 0.106 and 0.214 for the blend 
containing 1. The $I \mathrm{OH}$ and $I \mathrm{C}=\mathrm{CO}$ patterns indicated that tin-naphthalene complexes are also able to reduce the photooxidation of PVC films upon irradiation.

\subsection{Surface Morphology of PVC}

The role played by tin-naphthalene complexes 1-4 as stabilizers for PVC was investigated by examining the surface morphology of the irradiated films using optical microscopy. Optical microscopic images show any irregularities and roughness within the surface of PVC due to the release of $\mathrm{HCl}$ [52]. Figure 6 shows the optical images for the surface of irradiated and non-irradiated PVC (blank), and Figure 7 shows the optical images for the surface of PVC blended with tin-naphthalene complexes after irradiation. The irradiated PVC films showed rigid surfaces that contain a high number of cracks, white spots, and holes. For the PVC blended with tin-naphthalene complexes, the damage within the surface was less noticeable compared with that of the blank film. The tin-naphthalene complexes have the ability to act as scavengers for $\mathrm{HCl}$ and therefore reduce its negative effect on the PVC surface.
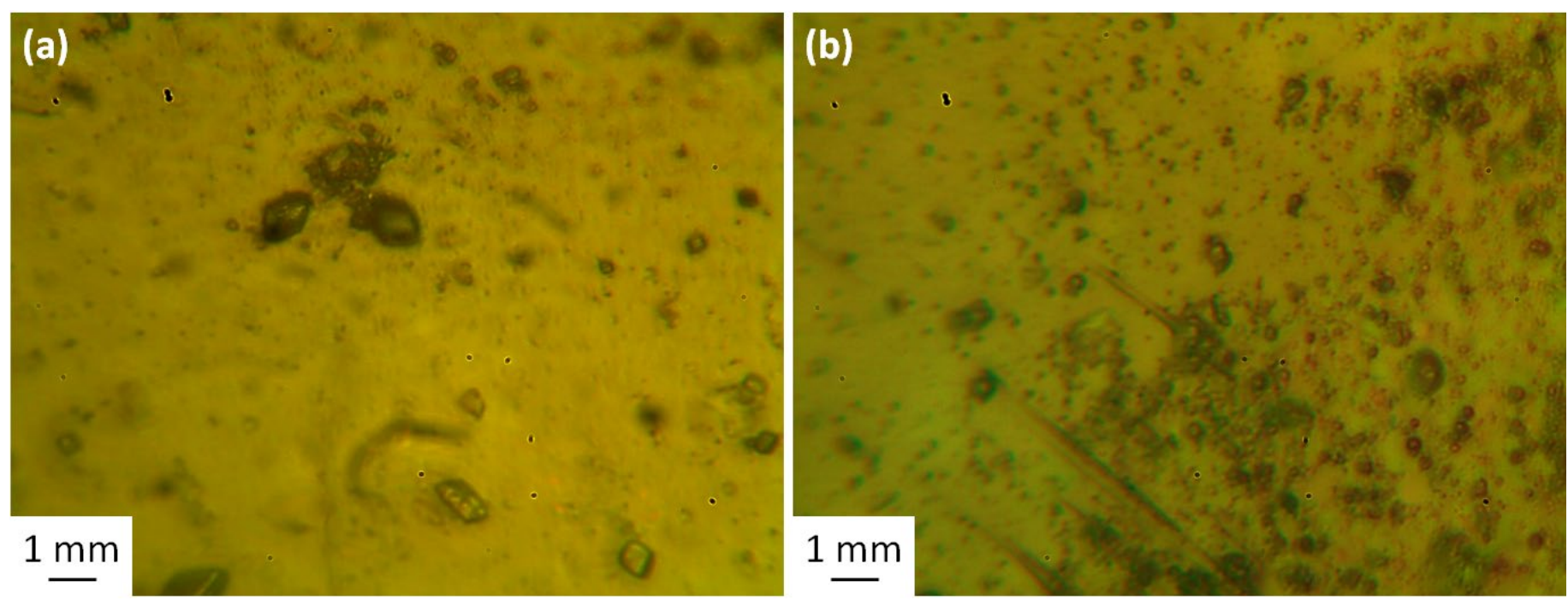

Figure 6. Optical microscopic images of PVC (blank) film: (a) before irradiation and (b) after irradiation.

Scanning electron microscopy (SEM) was used to investigate the variations that occurred within the surface of irradiated PVC [53]. The SEM images for the blank PVC films before and after irradiation are shown in Figure 8, whereas those blended with complexes 1-4 are shown in Figure 9. The surface of the PVC films was badly damaged in the case in which no additives were used. However, the surface defects were minimal within the surface of the blended PVC films, which reflects the role played by tin complexes in reducing photodegradation. The defects that appeared within the surface of the films are mainly a result of the elimination of volatiles (e.g., $\mathrm{HCl}$ ) and the cross-linking of chains. The surface of the PVC $+\mathbf{1}$ (Figure 9) was more or less smooth and regular, with a small number of cavities. The SEM images of the PVC films containing complexes 2-4 showed a regular particle aggregation. The pores within the surface were hexagonal and appeared as honeycomb like-structures, particularly in the presence of complex 4 (Figure 10). A similar phenomenon was observed for the irradiated PVC blended with a dithiazole Schiff base in the presence of nickel chloride [20]. The formation of the honeycomb structure could be due the slow dehydrochlorination process and the coordination of the additives with the polymeric chains [54]. By comparison, the irradiated PVC containing a melamine Schiff base showed an ice-rock structure [35]. 

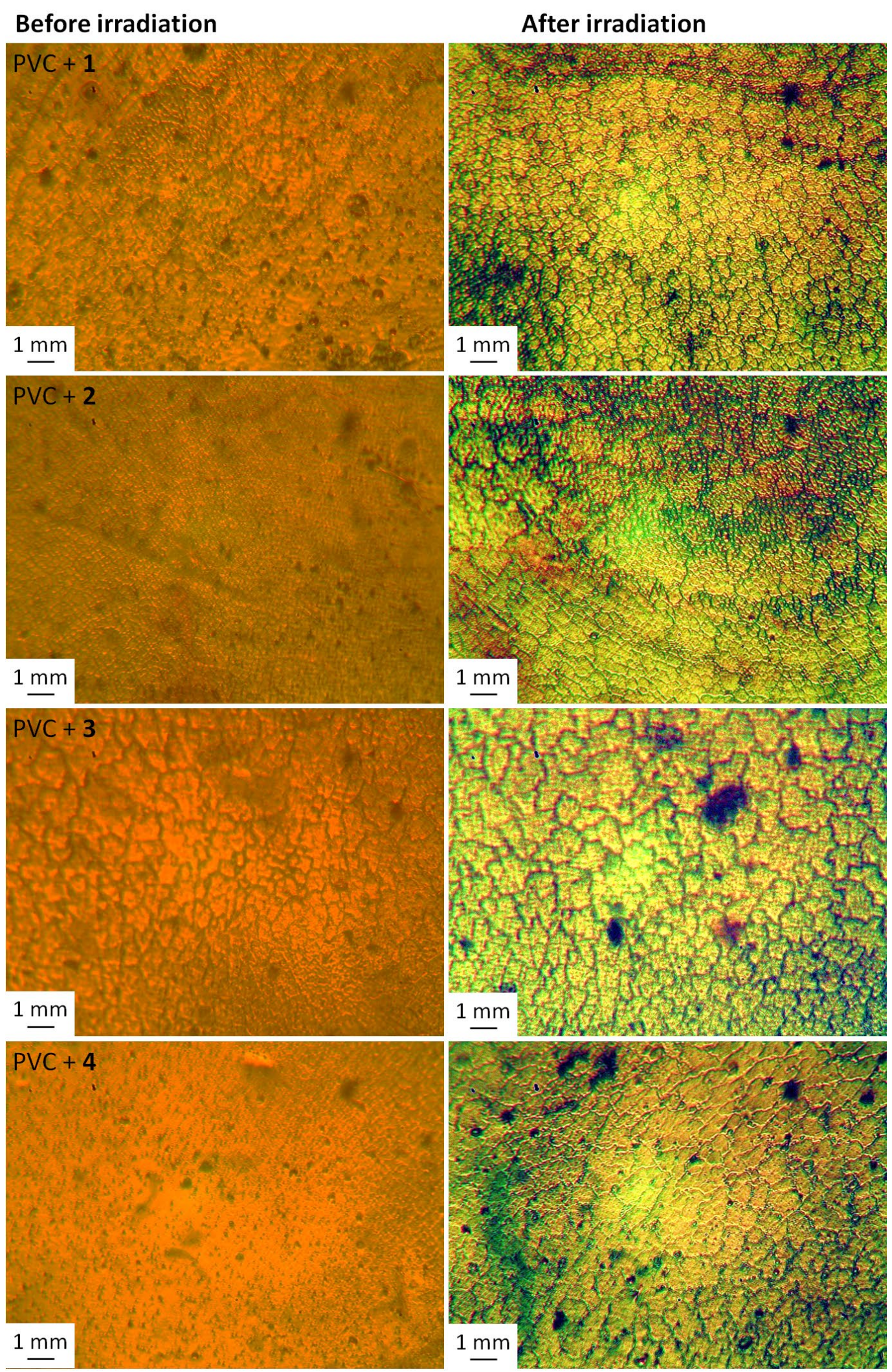

Figure 7. Optical microscopic images of PVC films before and after irradiation. 

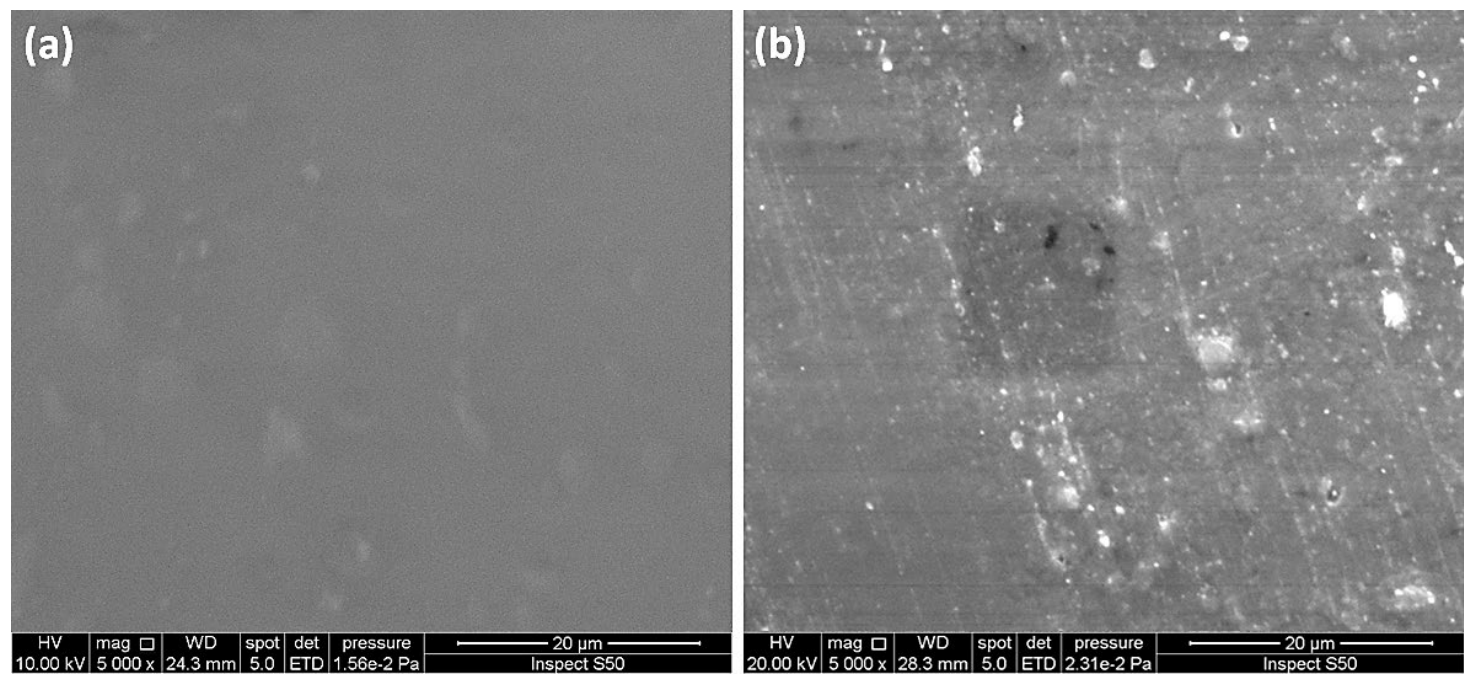

Figure 8. SEM images of the blank PVC film: (a) before irradiation and (b) after irradiation.
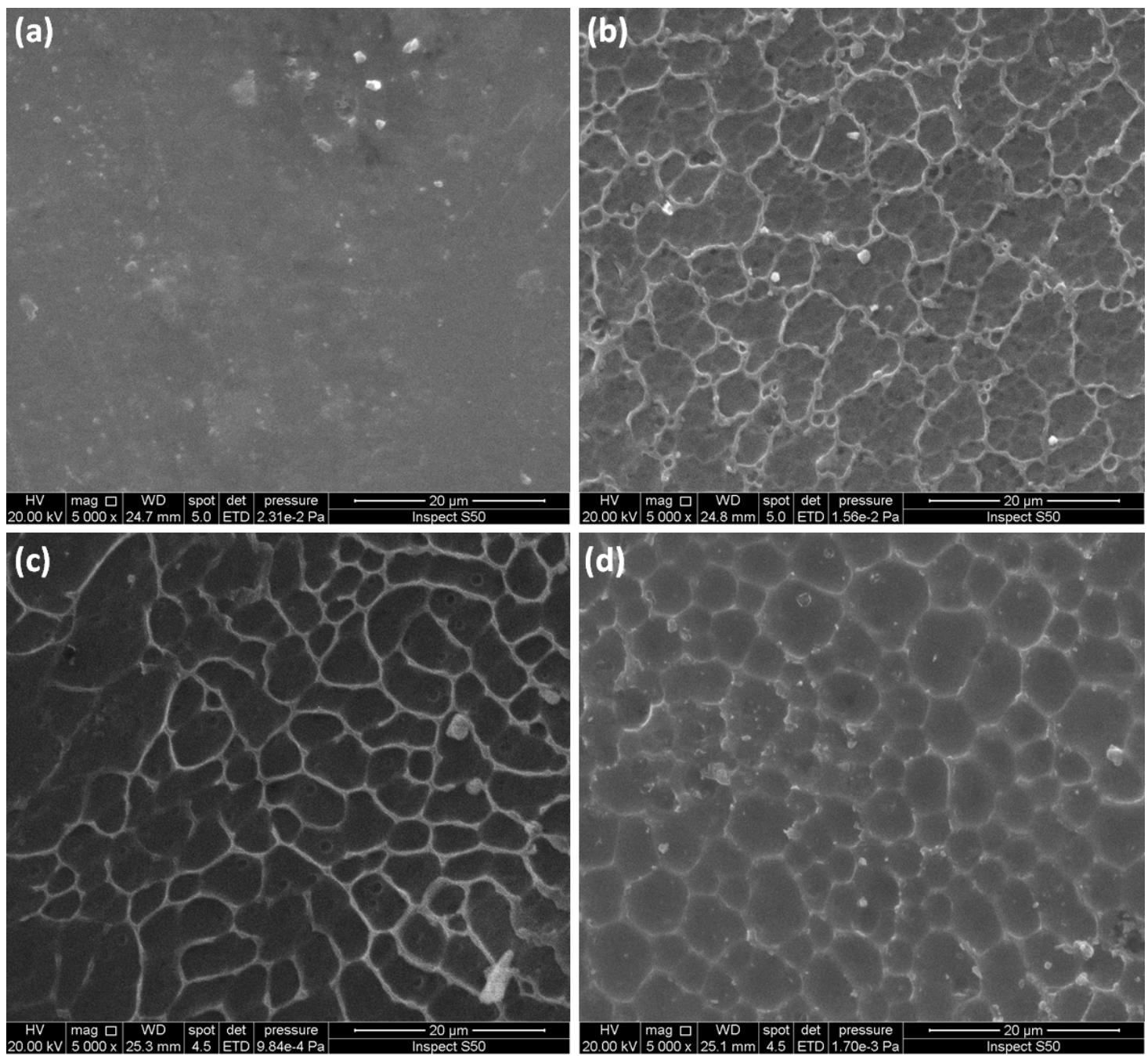

Figure 9. SEM images of PVC films after irradiation: (a) PVC $+\mathbf{1},(\mathbf{b}) \mathrm{PVC}+\mathbf{2},(\mathbf{c}) \mathrm{PVC}+\mathbf{3}$, and (d) PVC +4. 

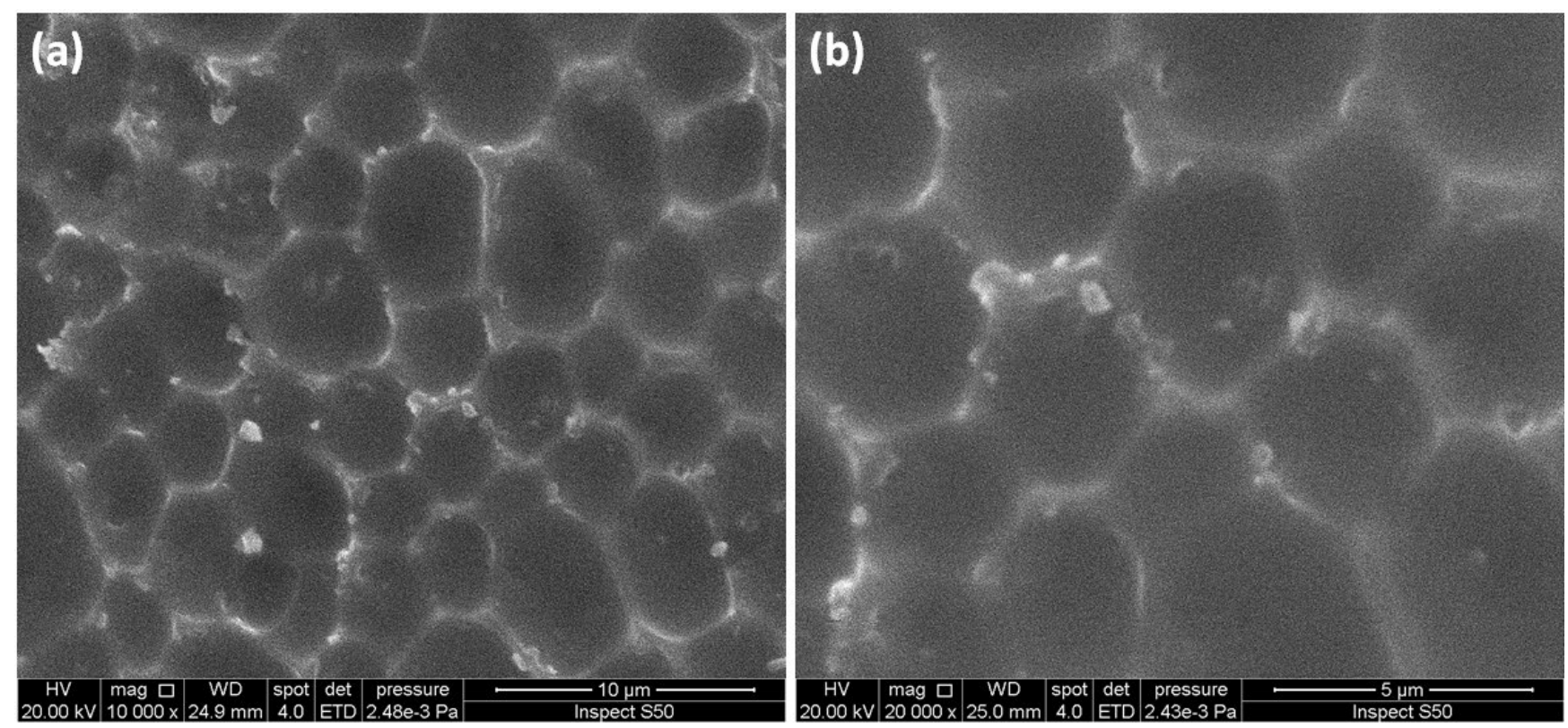

Figure 10. SEM images of PVC +4 at: (a) $10 \mu \mathrm{m}$ and (b) $5 \mu \mathrm{m}$.

The surface of the irradiated PVC blends was also investigated using atomic force microscopy (AFM). The AFM images show the smoothness and homogeneity of the surface without the need for a vacuum or electron beams [55]. Normally non-irradiated materials showed a surface with a high smoothness and homogeneity when inspected with AFM [56,57]. The AFM images (two- and three-dimensional) of the irradiated PVC films $(300 \mathrm{~h}$ ) are shown in Figure 11. These images indicate that the surface of the PVC blended with tin-naphthalene sulfonic acid complexes has a smoother and regular surface in comparison to the PVC (blank) film.

The roughness factor $(R q)$ was very high $(220)$ for the irradiated blank PVC film. The PVC films blended with tin complexes have a much lower $\mathrm{Rq}$ compared with the blank one after irradiation. The $\mathrm{Rq}$ was 3.7 for PVC $+1,10.3$ for PVC $+2,11.4$ for PVC + 3, and 12.6 PVC +4 films. Such a low $\mathrm{Rq}$ for the blended films indicated that tin complexes significantly reduced the bond breaking [58] and dehydrochlorination [59] of PVC. The use of complex 1 led to a reduction in the $R q$ by 59.5 -fold, which is the highest ever reported. For example, the fold-reduction in Rq of the irradiated PVC films was 5.2 over tin-naproxen complexes [60], 6.2 over tin-2-(4-isobutylphenyl)propanoate complexes [61], 6.6 over tin-furosemide complexes [62], 9.4 over tin-telmisartan complexes [63], and 16.6 over tin-ciprofloxacin complexes [64]. The use of Schiff bases led to a reasonable reduction (3.3-6.0) in the $R q$ [65-67], whereas polyphosphate containing benzidine caused a reduction in Rq by 16.7-fold [68]. The reductions obtained in Rq (by fold) of irradiated PVC in the presence of various photostabilizers are summarized in Table 4. 


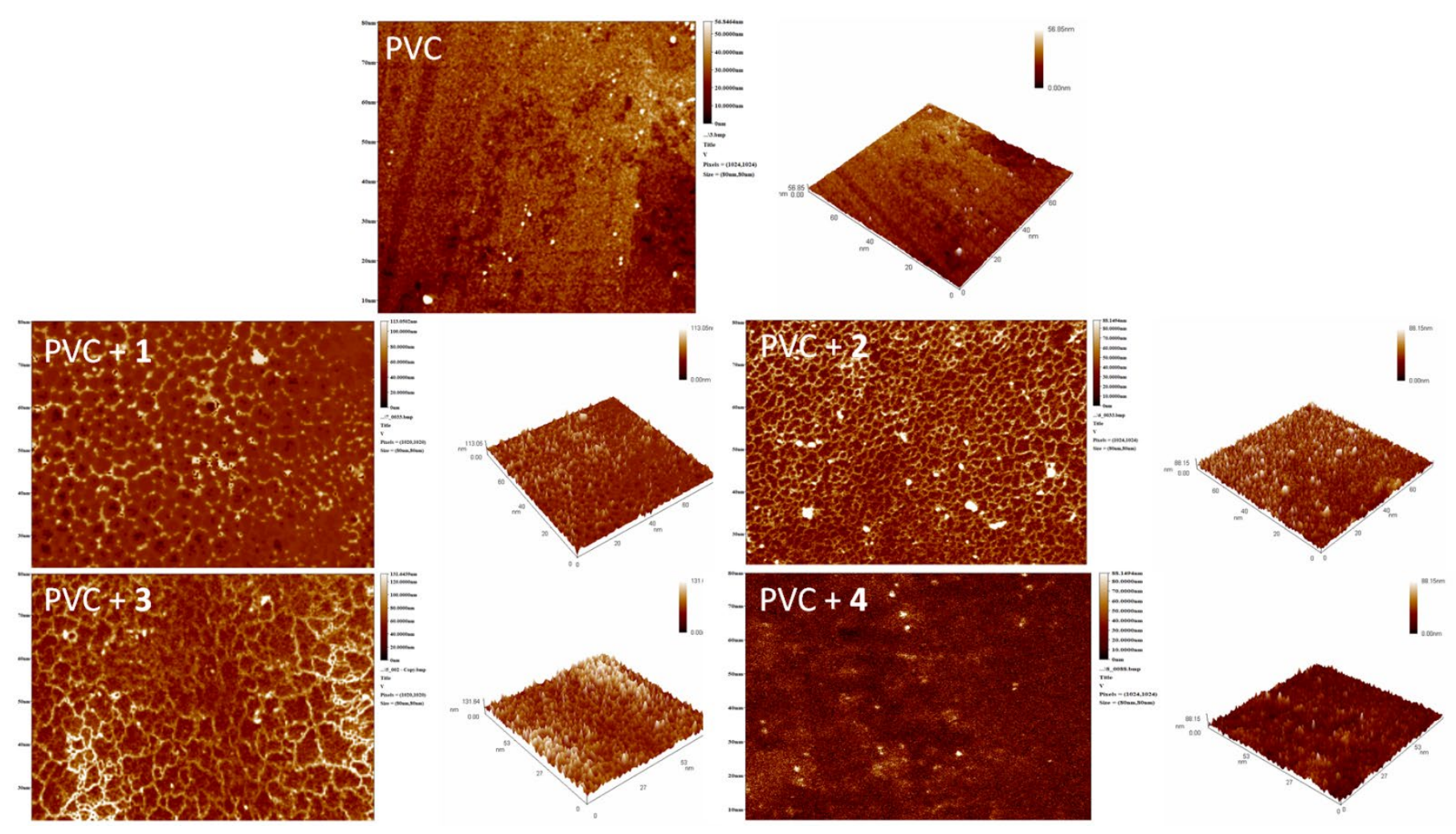

Figure 11. AFM images of irradiated PVC films.

Table 4. The effect of various additives on the $\mathrm{Rq}$ of PVC films.

\begin{tabular}{|c|c|c|}
\hline PVC Additive & $\mathrm{R} q$ Reduction in Fold & Reference \\
\hline Tin-naphthalene sulfonic acid complexes & 59.5 & Current work \\
\hline Tin-naproxen complexes & 5.2 & [57] \\
\hline Tin-2-(4-isobutylphenyl)propanoate complexes & 6.2 & [58] \\
\hline Tin-furosemide complexes & 6.6 & [59] \\
\hline Tin-telmisartan complexes & 9.4 & [60] \\
\hline Tin-ciprofloxacin complexes & 16.6 & [61] \\
\hline Schiff bases of 1,2,3,4-triazole-3-thiol & 3.3 & [62] \\
\hline Schiff bases of biphenyl-3, $3^{\prime}, 4,4^{\prime}$-tetraamine & 3.6 & [63] \\
\hline Schiff bases of melamine & 6.0 & [64] \\
\hline Polyphosphate containing benzidine & 16.7 & [65] \\
\hline
\end{tabular}

\subsection{Rate Constant of PVC Photodegradation}

The efficiency of tin-naphthalene complexes 1-4 as PVC photostabilizers was tested further through the determination of the rate constant of photodegradation $(\mathrm{Kd})$.

As shown in Table 5, the Kd value was highest $\left(9.80 \times 10^{-3} \mathrm{~s}^{-1}\right)$ for the blank PVC film and lowest for the blend containing complex $1\left(3.16 \times 10^{-3} \mathrm{~s}^{-1}\right)$. Clearly, the rate of photodegradation for the blank PVC was three times higher compared with the film containing 1. All other complexes showed a significant reduction in $\mathrm{Kd}\left(7.50-4.28 \times 10^{-3} \mathrm{~s}^{-1}\right)$ compared with that for the blank film. These results are consistent with those obtained from infrared, weight loss, specific functional groups' formation, and surface morphology. 
Table 5. Rate constant of photodegradation (Kd) of PVC films.

\begin{tabular}{cc}
\hline PVC Film & Rate Constant of PVC Photodegradation $\left(\right.$ Kd; s $\left.{ }^{-1}\right)$ \\
\hline PVC (blank) & $9.80 \times 10^{-3}$ \\
PVC + 1 & $3.16 \times 10^{-3}$ \\
PVC + 2 & $4.28 \times 10^{-3}$ \\
PVC + 3 & $6.30 \times 10^{-3}$ \\
PVC + 4 & $7.50 \times 10^{-3}$ \\
\hline
\end{tabular}

\subsection{Suggested Mechanisms for PVC Photostabilization}

Tin-naphthalene complexes 1-4 provided protection for PVC and reduced its photooxidation and photodegradation, in which $\mathbf{1}$ provided the greatest effect. Several mechanisms are proposed to highlight the role played by the complexes (particularly $\mathbf{1}$ ) as stabilizers for PVC (Figures 12-14). Complexes 1-4 contain an acidic center (tin atom) and therefore act as $\mathrm{HCl}$ scavengers (Figure 12) to produce substituted tin chloride along with the liberation of the ligand. The PVC photostabilization mechanisms are speculative based on scientific logic and previous reports $[17,36]$. However, it should be noted that the action of these additives within macromolecules or polymeric networks might be complex, and thus not simple or straightforward.<smiles>Nc1c(O[Sn](c2ccccc2)(c2ccccc2)c2ccccc2)cc(S(=O)(=O)O)c2ccccc12</smiles><smiles>C[C@H]1C[C@@H]1[SbH3](Cl)(Cl)[SnH3]</smiles><smiles>Nc1c(O)cc(S(=O)(=O)O)c2ccccc12</smiles>

Figure 12. Complex 1 acts as a scavenger for $\mathrm{HCl}$.<smiles>Nc1c(O[Sn](F)(c2ccccc2)c2ccccc2)cc(S(=O)(=O)O)c2ccccc12</smiles><smiles>Nc1c(O[Sn](c2ccccc2)(c2ccccc2)c2ccccc2)cc(S(=O)(=O)O)c2cccc(OOP)c12</smiles>

Figure 13. Complex 1 acts as a peroxide decomposer.

The additives used, and in particular complex 1, act through scavenging peroxide radicals (Figure 13), which are produced due to degradation of PVC in the presence of oxygen. The excited state containing additives and peroxide radicals (chromophore) is highly stable due to resonance. Additionally, the coordination between additives and PVC can stabilize the polymeric chain (Figure 14). 


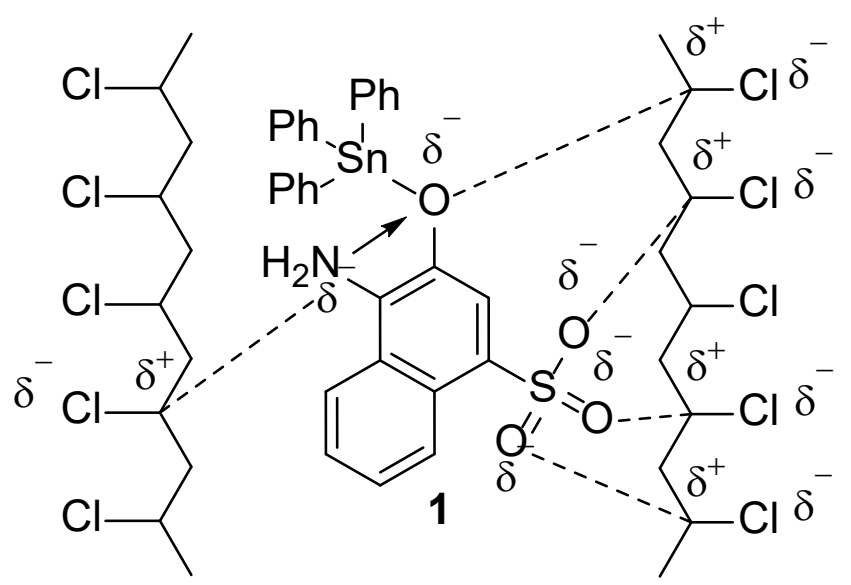

Figure 14. Attraction between PVC and Complex 1.

\section{Materials and Methods}

\subsection{Materials and Instrumentation}

Chemicals and solvents were purchased from Merck (Schnelldorf, Germany). PVC with an average molecular weight of approximately 250,000 was purchased from Petkim Petrokimya (Istanbul, Turkey). A Vario EL III elemental analyzer (Elementar Americas Inc., Ronkonkoma, NY, USA) was used to determine the contents of carbon, hydrogen, nitrogen, and sulfur in the complexes. An FTIR-4200 spectrometer (Jasco, Tokyo, Japan) was used for recording the infrared spectra using a potassium bromide disc. The ${ }^{1} \mathrm{H}$ and 119 Sn NMR spectra were recorded on a Bruker DRX500 spectrometer (Zürich, Switzerland) in dimethyl sulfoxide (deuterated) at 500 and $149 \mathrm{MHz}$, respectively. The weathering tests were performed at room temperature on a Q-Panel tester (Homestead, FL, USA) and the surface morphology was examined using Inspect S50 (FEI Company, Czech Republic), KYKY-EM3200 (Ontario, CA, USA), and Meiji Techno (Tokyo, Japan) microscopes.

\subsection{Synthesis of Trisubstituted Tin-Naphthalene Sulfonic acid Complexes $\mathbf{1}$ and $\mathbf{2}$}

A stirred mixture of 4-amino-3-hydroxynaphthalene-1-sulfonic acid (1.20 g, $5 \mathrm{mmol})$ and triphenyltin chloride $(1.93 \mathrm{~g}, 5 \mathrm{mmol})$ or tributyltin chloride $(1.63 \mathrm{~g}, 5 \mathrm{mmol})$ in $\mathrm{MeOH}$ $(60 \mathrm{~mL})$ was refluxed for $4 \mathrm{~h}$. The mixture was left at room temperature to cool down, and the solid produced was filtered, washed with $\mathrm{MeOH}$, and dried to give complex $\mathbf{1}$ or 2 (Scheme 1) with a $75 \%$ or $70 \%$ yield respectively (Table 1 ).

\subsection{Synthesis of Disubstituted Tin-Naphthalene Sulfonic acid Complexes $\mathbf{3}$ and $\mathbf{4}$}

A stirred mixture of 4-amino-3-hydroxynaphthalene-1-sulfonic acid $(1.43 \mathrm{~g}, 6 \mathrm{mmol})$ and dibutyltin dichloride $(091 \mathrm{~g}, 2.5 \mathrm{mmol})$ or dimethyltin dichloride $(0.66 \mathrm{~g}, 3 \mathrm{mmol})$ in $\mathrm{MeOH}(40 \mathrm{~mL})$ was refluxed for $4 \mathrm{~h}$. The mixture was left at room temperature to cool down and the solid produced was filtered, washed with $\mathrm{MeOH}$, and dried to produce complex 3 or 4 (Scheme 2) with a 95\% or 89\% yield respectively (Table 1).

\subsection{Preparation of PVC Films}

The PVC films were prepared using the casting solution technique. To a stirred solution of PVC (5 g) in tetrahydrofuran (THF; $100 \mathrm{~mL})$, tin complex (25 mg) was added. The solution was stirred for three hours then poured into a glass plate that contained 15 holes with a thickness of approximately $40 \mu \mathrm{m}$. The produced films were left to dry for a day at room temperature followed by eight hours at a reduced pressure using a vacuum oven. 


\subsection{Exposure to UV Light}

The PVC films were exposed to UV light $(365 \mathrm{~nm})$ with a light intensity of $6.2 \times 10^{-9}$ ein $\mathrm{dm}^{-3} \mathrm{~s}^{-1} \mathrm{~nm}$ for a period of time that ranged from 50 to $300 \mathrm{~h}$ at room temperature.

\section{Conclusions}

Four new tin-naphthalene sulfonic acid complexes were synthesized in good yields and their structures were elucidated. The tin complexes were added to PVC as additives and thin films were made. The tin complexes acted as photostabilizers for PVC upon the exposure to ultraviolet light for a long period of time. Various tools such as infrared analysis, weight loss, specific functional groups' formation, surface morphology, and rate constant of photodegradation were used to test the effectiveness of the additives as photostabilizers. The complexes significantly reduced photodegradation and photooxidation of PVC by acting as peroxide decomposers, hydrogen chloride scavengers, and energy absorbers. In addition, the roughness factor of the surface for the irradiated films containing tin complexes was very low. The highly aromatic complex, which contains three phenyl substituents, showed the most stabilizing effect through efficient absorption of light energy.

Author Contributions: Conceptualization and experimental design: G.A.E.-H., M.A.B., H.H., A.A.A., D.S.A. and E.Y.; experimental work and data analysis: H.J. and A.G.H.; writing-original draft preparation: G.A.E.-H., D.S.A. and E.Y; and writing-review and editing: G.A.E.-H., D.S.A. and E.Y. All authors have read and agreed to the published version of the manuscript.

Funding: The authors are grateful to the Deanship of Scientific Research, King Saud University for funding through Vice Deanship of Scientific Research Chairs.

Institutional Review Board Statement: Not applicable.

Informed Consent Statement: Not applicable.

Data Availability Statement: Data are contained within the article.

Acknowledgments: We thank Babylon and Al-Nahrain Universities for technical support.

Conflicts of Interest: The authors declare no conflict of interest.

Sample Availability: Samples of tin-naphthalene complexes are available from the authors.

\section{References}

1. Andrady, A.L.; Neal, M.A. Applications and societal benefits of plastics. Philos. Trans. R. Soc. Lond. B Biol. Sci. 2009, 364, 1977-1984. [CrossRef] [PubMed]

2. Geyer, R.; Jambeck, J.R.; Law, K.L. Production, use, and fate of all plastics ever made. Sci. Adv. 2017, 3, e1700782. [CrossRef] [PubMed]

3. Everard, M. Twenty years of the polyvinyl chloride sustainability challenges. J. Vinyl Addit. Technol. 2020, 26, 390-402. [CrossRef]

4. Patrick, S.G. Practical Guide to Polyvinyl Chloride; Rapra Technology Limited: Shrewsbury, UK, 2005.

5. Cadogan, D.F.; Howick, C.J. Plasticizers. In Ullmann's Encyclopedia of Industrial Chemistry; Wiley-VCH: Weinheim, Germany, 2000.

6. Liu, J.; Lv, Y.; Luo, Z.; Wang, H.; Wei, Z. Molecular chain model construction, thermo-stability, and thermo-oxidative degradation mechanism of poly(vinyl chloride). RSC Adv. 2016, 6, 31898-31905. [CrossRef]

7. Al-Hashem, H.A.S.; Al-Naeem, M.A.H. Effect of temperature on the stiffness of polyvinyl chloride and chlorinated polyvinyl chloride joints under bending. J. Appl. Sci. 2007, 7, 3442-3450. [CrossRef]

8. Kaczmarek, H.; Kowalonek, J.; Ołdak, D. The influence of UV-irradiation on poly(vinyl chloride) modified by iron and cobalt chlorides. Polym. Degrad. Stab. 2003, 79, 231-240. [CrossRef]

9. Kaczmarek, H.; Świątek, M.; Kamińska, A. Modification of polystyrene and poly(vinyl chloride) for the purpose of obtaining packaging materials degradable in the natural environment. Polym. Degrad. Stab. 2004, 83, 35-40. [CrossRef]

10. Chaochanchaikul, K.; Rosarpitak, V.; Sombatsompop, N. Photodegradation profiles of PVC compound and wood/PVC composites under UV weathering. Express Polym. Lett. 2013, 7, 146-160. [CrossRef]

11. Rabek, J.F. Polymer Photodegradation. Mechanisms and Experimental Methods; Chapman \& Hall: London, UK, 1995.

12. Huang, Z.; Ding, A.; Guo, H.; Lu, G.; Huang, X. Construction of nontoxic polymeric UV-absorber with great resistance to UV-photoaging. Sci. Rep. 2016, 6, 25508. [CrossRef]

13. Folarin, O.M.; Sadiku, E.R. Thermal stabilizers for poly(vinyl chloride): A review. Int. J. Phys. Sci. 2011, 6, 4323-4330. [CrossRef]

14. Schiller, M. PVC Additives: Performance, Chemistry, Developments, and Sustainability; Carl Hanser Verlag: Munich, Germany, 2015. 
15. Real, L.P.; Ferraria, A.M.; Rego, A.B. Comparison of different photo-oxidation conditions of poly(vinyl chloride) for outdoor applications. Polym. Test. 2008, 27, 743-751. [CrossRef]

16. Babinsky, R. PVC additives: A global review. Plast. Addit. Compd. 2006, 8, 38-40. [CrossRef]

17. Balakit, A.A.; Ahmed, A.; El-Hiti, G.A.; Smith, K.; Yousif, E. Synthesis of new thiophene derivatives and their use as photostabilizers for rigid poly(vinyl chloride). Int. J. Polym. Sci. 2015, 2015, 510390. [CrossRef]

18. Ahmed, A.A.; Ahmed, D.S.; El-Hiti, G.A.; Alotaibi, M.H.; Hashim, H.; Yousif, E. SEM morphological analysis of irradiated polystyrene film doped by a Schiff base containing a 1,2,4-triazole ring system. Appl. Petrochem. Res. 2019, 9, 169-177. [CrossRef]

19. Shaalan, N.; Laftah, N.; El-Hiti, G.A.; Alotaibi, M.H.; Muslih, R.; Ahmed, D.S.; Yousif, E. Poly(vinyl chloride) photostabilization in the presence of Schiff bases containing a thiadiazole moiety. Molecules 2018, 23, 913. [CrossRef]

20. Hashim, H.; El-Hiti, G.A.; Alotaibi, M.H.; Ahmed, D.S.; Yousif, E. Fabrication of ordered honeycomb porous poly(vinyl chloride) thin film doped with a Schiff base and nickel(II) chloride. Heliyon 2018, 4, e00743. [CrossRef]

21. Ali, G.Q.; El-Hiti, G.A.; Tomi, I.H.R.; Haddad, R.; Al-Qaisi, A.J.; Yousif, E. Photostability and performance of polystyrene films containing 1,2,4-triazole-3-thiol ring system Schiff bases. Molecules 2016, 21, 1699. [CrossRef]

22. Yang, T.C.; Noguchi, T.; Isshiki, M.; Wu, J.H. Effect of titanium dioxide particles on the surface morphology and the mechanical properties of PVC composites during QUV accelerated weathering. Polym. Compos. 2016, 37, 3391-3397. [CrossRef]

23. Yang, T.C.; Noguchi, T.; Isshiki, M.; Wu, J.H. Effect of titanium dioxide on chemical and molecular changes in PVC sidings during QUV accelerated weathering. Polym. Degrad. Stab. 2014, 104, 33-39. [CrossRef]

24. Chakrabarti, S.; Chaudhuri, B.; Bhattacharjee, S.; Das, P.; Dutta, B.K. Degradation mechanism and kinetic model for photocatalytic oxidation of PVC-ZnO composite film in presence of a sensitizing dye and UV radiation. J. Hazard Mater. 2008, 154, 230-236. [CrossRef]

25. El-Hiti, G.A.; Ahmed, D.S.; Yousif, E.; Alotaibi, M.H.; Star, H.A.; Ahmed, A.A. Influence of polyphosphates on the physicochemical properties of poly(vinyl chloride) after irradiation with ultraviolet light. Polymers 2020, 12, 193. [CrossRef]

26. Jin, D.; Khanal, S.; Zhang, C.; Xu, S. Photodegradation of polybenzimidazole/polyvinyl chloride composites and polybenzimidazole: Density functional theory and experimental study. J. Appl. Polym. Sci. 2021, 138, 49693. [CrossRef]

27. Devi, J.; Yadav, J. Recent advancements in organotin(IV) complexes as potential anticancer agents. Anticancer Agents Med. Chem. 2018, 18, 335-353. [CrossRef]

28. Sirajuddin, M.; Ali, S. Organotin(IV) carboxylates as promising potential drug candidates in the field of cancer chemotherapy. Curr. Pharm. Des. 2016, 22, 6665-6681. [CrossRef]

29. Romero-Chávez, M.M.; Pineda-Urbina, K.; Pérez, D.J.; Obledo-Benicio, F.; Flores-Parra, A.; Gómez-Sandoval, Z.; Ramos-Organillo, Á. Organotin(IV) compounds derived from ibuprofen and cinnamic acids, an alternative into design of anti-inflammatory by the cyclooxygenases (COX-1 and COX-2) pathway. J. Organomet. Chem. 2018, 862, 58-70. [CrossRef]

30. Shah, S.S.A.; Ashfaq, M.; Waseem, A.; Ahmed, M.M.; Najam, T.; Shaheen, S.; Rivera, G. Synthesis and biological activities of organotin(IV) complexes as antitumoral and antimicrobial agents. A review. Mini Rev. Med. Chem. 2015, 15, 406-426. [CrossRef]

31. Iqbal, H.; Ali, S.; Shahzadi, S. Antituberculosis study of organotin(IV) complexes: A review. Cogent Chem. 2015, 1, 1029039. [CrossRef]

32. Davies, A.G. Organotin Chemistry, 2nd ed.; Wiley-VCH: Weinheim, Germany, 2004.

33. Da Silva, M.A.; dos Santos, A.S.S.; dos Santos, T.V.; Meneghetti, M.R.; Meneghetti, S.M.P. Organotin(IV) compounds with high catalytic activities and selectivities in the glycerolysis of triacylglycerides. Catal. Sci. Technol. 2017, 7, 5750-5757. [CrossRef]

34. Ghazi, D.; Rasheed, Z.; Yousif, E. A review of organotin compounds: Chemistry and applications. Arch. Org. Inorg. Chem. Sci. 2018, 3, 344-352. [CrossRef]

35. Ahmed, A.; El-Hiti, G.A.; Hadi, A.G.; Ahmed, D.S.; Baashen, M.A.; Hashim, H.; Yousif, E. Photostabilization of poly(vinyl chloride) films blended with organotin complexes of mefenamic acid for outdoor applications. Appl. Sci. 2021, 11, 2853. [CrossRef]

36. Mousa, O.G.; El-Hiti, G.A.; Baashen, M.A.; Bufaroosha, M.; Ahmed, A.; Ahmed, A.A.; Ahmed, D.S.; Yousif, E. Synthesis of carvedilol-organotin complexes and their effects on reducing photodegradation of poly(vinyl chloride). Polymers 2021, 13, 500. [CrossRef] [PubMed]

37. Mahmood, Z.N.; Yousif, E.; Alias, M.; El-Hiti, G.A.; Ahmed, D.S. Synthesis, characterization, properties, and use of new fusidate organotin complexes as additives to inhibit poly(vinyl chloride) photodegradation. J. Polym. Res. 2020, 27, 267. [CrossRef]

38. Kavitha, P.; Reddy, K.L. Synthesis, spectral characterisation, morphology, biological activity and DNA cleavage studies of metal complexes with chromone Schiff base. Arab. J. Chem. 2016, 9, 596-605. [CrossRef]

39. Tarafder, M.T.H.; Chew, K.-B.; Crouse, K.A.; Ali, M.A.; Yamin, B.M.; Fun, H.-K. Synthesis and characterization of Cu(II), Ni(II) and $\mathrm{Zn}(\mathrm{II})$ metal complexes of bidentate NS isomeric Schiff bases derived from S-methyldithiocarbazate (SMDTC): Bioactivity of the bidentate NS isomeric Schiff bases, some of their $\mathrm{Cu}(\mathrm{II}), \mathrm{Ni}(\mathrm{II})$ and $\mathrm{Zn}(\mathrm{II})$ complexes and the X-ray structure of the bis[S-methyl- $\beta$-N-(2-furyl-methyl)methylenedithiocarbazato]zinc(II) complex. Polyhedron 2002, 21, 2683-2690. [CrossRef]

40. Morozov, O.S.; Vyshinskii, N.N.; Rudnevskii, N.K. Investigation of some organotin compounds and their complexes by IR spectroscopy. J. Appl. Spectrosc. 1981, 35, 1019-1023. [CrossRef]

41. Masood, H.; Ali, S.; Mazhar, M.; Shahzadi, S.; Shahid, K. ${ }^{1} \mathrm{H},{ }^{13} \mathrm{C},{ }^{119} \mathrm{Sn}$ NMR, Mass, Mössbauer and biological studies of tri-, diand chlorodiorganotin(IV) carboxylates. Turk. J. Chem. 2004, 28, 75-86. 
42. Shahid, K.; Ali, S.; Shahzadi, S.; Badshah, A.; Khan, K.M.; Maharvi, G.M. Organotin(IV) complexes of aniline derivatives. I. Synthesis, spectral and antibacterial studies of di- and triorganotin(IV) derivatives of 4-bromomaleanilic acid. Synth. React. Inorg. Met-Org. Chem. 2003, 33, 1221-1235. [CrossRef]

43. Rehman, W.; Baloch, M.K.; Badshah, A.; Ali, S. Synthesis and characterization of biologically potent di-organotin(IV) complexes of mono-methyl glutarate. J. Chin. Chem. Soc. 2005, 52, 231-236. [CrossRef]

44. Göpferich, A. Mechanisms of polymer degradation and erosion. Biomaterials 1996, 17, 103-114. [CrossRef]

45. Jafari, A.J.; Donaldson, J.D. Determination of $\mathrm{HCl}$ and VOC emission from thermal degradation of PVC in the absence and presence of copper, copper(II) oxide and copper(II) chloride. J. Chem. 2009, 6, 685-692. [CrossRef]

46. Nief, O.A. Photostabilization of polyvinyl chloride by some new thiadiazole derivatives. Eur. J. Chem. 2015, 6, 242-247. [CrossRef]

47. Gardette, J.L.; Gaumet, S.; Lemaire, J. Photooxidation of poly(vinyl chloride). 1. A reexamination of the mechanism. Macromolecules 1989, 22, 2576-2581. [CrossRef]

48. Almond, J.; Sugumaar, P.; Wenzel, M.N.; Hill, G.; Wallis, C. Determination of the carbonyl index of polyethylene and polypropylene using specified area under band methodology with ATR-FTIR spectroscopy. e-Polymers 2020, 20, 369-381. [CrossRef]

49. Rabek, J.F.; Shur, Y.J.; Rårnby, B. Studies of the photooxidation mechanism of polymers. III. Role of tetrahydrofuran in the photooxidative degradation of poly(vinyl chloride). J. Polym. Sci. Pol. Chem. 1975, 13, 1285-1295. [CrossRef]

50. Mehmandoust, S.G.; Sokhandani, P.; Abdi, A.M.; Babaluo, A.A.; Alizadeh, R. Effect of long time exposure on the chemical and physical properties of polyvinyl chloride/titanium dioxide nanocomposites. J. Thermoplast. Compos. Mater. 2016, 29, 1498-1516. [CrossRef]

51. Sokhandani, P.; Babaluo, A.A.; Rezaei, M.; Shahrezaei, M.; Hasanzadeh, A.; Mehmandoust, S.G.; Mehdizadeh, R. Nanocomposites of $\mathrm{PVC} / \mathrm{TiO}_{2}$ nanorods: Surface tension and mechanical properties before and after UV exposure. J. Appl. Polym. Sci. 2013, 129, 3265-3272. [CrossRef]

52. Valko, L.; Klein, E.; Kovařík, P.; Bleha, T.; Šimon, P. Kinetic study of thermal dehydrochlorination of poly(vinyl chloride) in the presence of oxygen: III. Statistical thermodynamic interpretation of the oxygen catalytic activity. Eur. Polym. J. 2001, 37, 1123-1132. [CrossRef]

53. Mehmood, N.; Andreasson, E.; Kao-Walter, S. SEM observations of a metal foil laminated with a polymer film. Procedia Mater. Sci. 2014, 3, 1435-1440. [CrossRef]

54. Huh, M.; Gauthier, M.; Yun, S. Honeycomb structured porous films prepared from arborescent graft polystyrenes via the breath figures method. Polymer 2016, 107, 273-281. [CrossRef]

55. Kara, F.; Aksoy, E.A.; Yuksekdag, Z.; Hasirci, N.; Aksoy, S. Synthesis and surface modification of polyurethanes with chitosan for antibacterial properties. Carbohydr. Polym. 2014, 112, 39-47. [CrossRef]

56. Yousif, E.; Ahmed, D.S.; El-Hiti, G.A.; Alotaibi, M.H.; Hashim, H.; Hameed, A.S.; Ahmed, A. Fabrication of novel ball-like polystyrene films containing Schiff base microspheres as photostabilizers. Polymers 2018, 10, 1185. [CrossRef]

57. Alotaibi, M.H.; El-Hiti, G.A.; Yousif, E.; Ahmed, D.S.; Hashim, H.; Hameed, A.S.; Ahmed, A. Evaluation of the use of polyphosphates as photostabilizers and in the formation of ball-like polystyrene materials. J. Polym. Res. 2019, 26, 161. [CrossRef]

58. Zheng, X.-G.; Tang, L.-H.; Zhang, N.; Gao, Q.-H.; Zhang, C.-F.; Zhu, Z.-B. Dehydrochlorination of PVC materials at high temperature. Energy Fuels 2003, 17, 896-900. [CrossRef]

59. Shi, W.; Zhang, J.; Shi, X.-M.; Jiang, G.-D. Different photodegradation processes of PVC with different average degrees of polymerization. J. Appl. Polym. Sci. 2008, 107, 528-540. [CrossRef]

60. Hadi, A.G.; Yousif, E.; El-Hiti, G.A.; Ahmed, D.S.; Jawad, K.; Alotaibi, M.H.; Hashim, H. Long-term effect of ultraviolet irradiation on poly(vinyl chloride) films containing naproxen diorganotin(IV) complexes. Molecules 2019, 24, 2396. [CrossRef]

61. Mohammed, R.; El-Hiti, G.A.; Ahmed, A.; Yousif, E. Poly(vinyl chloride) doped by 2-(4-isobutylphenyl)propanoate metal complexes: Enhanced resistance to UV irradiation. Arab. J. Sci. Eng. 2017, 42, 4307-4315. [CrossRef]

62. Ali, M.M.; El-Hiti, G.A.; Yousif, E. Photostabilizing efficiency of poly(vinyl chloride) in the presence of organotin(IV) complexes as photostabilizers. Molecules 2016, 21, 1151. [CrossRef]

63. Hadi, A.G.; Jawad, K.; El-Hiti, G.A.; Alotaibi, M.H.; Ahmed, A.A.; Ahmed, D.S.; Yousif, E. Photostabilization of poly(vinyl chloride) by organotin(IV) compounds against photodegradation. Molecules 2019, 24, 3557. [CrossRef] [PubMed]

64. Ghazi, D.; El-Hiti, G.A.; Yousif, E.; Ahmed, D.S.; Alotaibi, M.H. The effect of ultraviolet irradiation on the physicochemical properties of poly(vinyl chloride) films containing organotin(IV) complexes as photostabilizers. Molecules 2018, 23, 254. [CrossRef] [PubMed]

65. Yousif, E.; Hasan, A.; El-Hiti, G.A. Spectroscopic, physical and topography of photochemical process of PVC films in the presence of Schiff base metal complexes. Polymers 2016, 8, 204. [CrossRef] [PubMed]

66. Ahmed, D.S.; El-Hiti, G.A.; Hameed, A.S.; Yousif, E.; Ahmed, A. New tetra-Schiff bases as efficient photostabilizers for poly(vinyl chloride). Molecules 2017, 22, 1506. [CrossRef]

67. El-Hiti, G.A.; Alotaibi, M.H.; Ahmed, A.A.; Hamad, B.A.; Ahmed, D.S.; Ahmed, A.; Hashim, H.; Yousif, E. The morphology and performance of poly(vinyl chloride) containing melamine Schiff bases against ultraviolet light. Molecules 2019, 24, 803. [CrossRef]

68. Ahmed, D.S.; El-Hiti, G.A.; Yousif, E.; Hameed, A.S. Polyphosphates as inhibitors for poly(vinyl chloride) photodegradation. Molecules 2017, 22, 1849. [CrossRef] 